\title{
Charakterystyczne zmiany strukturalne i finansowe przedsiębiorstw w Polsce w latach 1999-2003
}

https://doi.org/10.33141/po.2005.09.03

\section{Barbara Siuta}

\section{Wstęp}

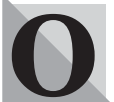
stanie gospodarki polskiej, wciąż ulegającej dalszym przekształceniom gospodarczym, można sądzić przede wszystkim na podstawie obserwowanych zmian strukturalnych przedsiębiorstw oraz ich kondycji finansowej. Na tej podstawie można bowiem wyciagać odpowiednie wnioski, dotyczące kierunków zachodzących zmian oraz sytuacji ekonomicznej wynikającej z działalności przedsiębiorstw.

Zmiany strukturalne przedsiębiorstw w Polsce związane są głównie z realizowaną od kilkunastu lat prywatyzacją przedsiębiorstw państwowych oraz stwarzaniem odpowiednich warunków do powstawania nowych przedsiębiorstw, stanowiących w decydującym zakresie zakłady osób fizycznych. Stąd celowe jest dokonanie oceny pod tym względem zaistniałych zmian w latach 1999-2003, przy odnotowaniu w podziale strukturalnym przedsiębiorstw - według ich stanu ilościowego - w poszczególnych latach, dokonanym m.in. według sektorów działalności przedsiębiorstw, według form organizacyjno-prawnych oraz według sekcji zgodnych z Polską Klasyfikacją Działalności.

Oprócz zmian strukturalnych, niezwykle interesującą informację stanowią dane, dotyczące sytuacji finansowej przedsiębiorstw w Polsce. O sytuacji tej można sądzić na podstawie materiałów źródłowych, opracowanych w skali makro w odniesieniu do przyjmowanego podziału przedsiębiorstw na małe, średnie i duże. Zebrane dane powinny uwzględniać charakterystyczne wskaźniki finansowe, związane z działalnością przedsiębiorstw, w tym wyniki finansowe i stopy rentowności, dane bilansowe, a na ich podstawie obliczone wskaźniki dotyczące zadłużenia i płynności finansowej oraz wskaźniki dotyczące działalności eksportowej i aktywności inwestycyjnej. Informacje takie dają podstawę do analizy zaistniałych zmian w sytuacji finansowej przedsiębiorstw w Polsce.

\section{Zmiany strukturalne przedsiębiorstw w Polsce}

kres przemian systemowych i gospodarczych, zapoczątkowany w latach 90. ub. stulecia, skutkuje nadal wyraźnymi zmianami w struk-
Przegląd Organizacji, Nr 9 (788), 2005, ss. 14-19 www.przegladorganizacji.pl Towarzystwo Naukowe Organizacji i Kierownictwa (TNOiK) turze i liczbie przedsiębiorstw w Polsce. Zaobserwować można szczególną dominację ilościową przedsiębiorstw sektora prywatnego, z przeważającym udziałem przedsiębiorstw grupy MSP, tj. mikroprzedsiębiorstw, małych i średnich przedsiębiorstw. W rezultacie tworzenia nowych, prywatnych przedsiębiorstw w latach 1999-2003 liczba podmiotów gospodarczych sektora prywatnego systematycznie wzrastała: z 2956,1 tys. w 1999 r. do 3452,3 tys. w 2003 r $^{11}$. Liczba przedsiębiorstw sektora publicznego na tle ogółu przedsiębiorstw w tych latach była stosunkowo mała, choć również cechowała się podobnym przyrostem, jak w przypadku sektora prywatnego: w $1999 \mathrm{r}$. - 83,3 tys., a w 2003 r. - 129,3 tys. podmiotów gospodarczych ${ }^{2}$.

W tabeli 1 przedstawiono liczbę przedsiębiorstw w Polsce w latach 1999-2003 z uwzglednieniem sektorów działalności przedsiębiorstw oraz ich formy organizacyjno-prawnej.

Jak wynika $\mathrm{z}$ danych zawartych $\mathrm{w}$ tabeli 1 , największą liczbę podmiotów gospodarczych w latach 1999-2003 odnotowano w grupie ,zakłady osób fizycznych", gdzie liczba podmiotów zarejestrowanych wyniosła blisko ponad 2,5 mln jednostek, stanowiąc $78 \%$ podmiotów o tej formie organizacyjno-prawnej na tle ogółu przedsiębiorstw. Ta forma działalności uznawana jest za jedna z bardziej korzystnych form prowadzenia działalności gospodarczej, co niewątpliwie związane jest z jej licznymi zaletami, jak np. szybki, tani i łatwy proces rejestracji, brak wymogów odnośnie do minimalnej wartości kapitału założycielskiego, łatwość rozszerzania działalności i likwidacji itp. Dość atrakcyjną formą prowadzenia działalności gospodarczej są również spółki prawa handlowego oraz spółki cywilne. Generalnie biorąc w latach 1999-2003 liczba przedsiębiorstw przyjmujących taką formę organizacyjnoprawną prowadzenia działalności gospodarczej wzrosła z 435,8 tys. w 1999 r. do 488 tys. w 2003 r. Wśród krajowych przedsiębiorców prywatnych najczęściej prowadzoną formą działalności gospodarczej w postaci spółek prawa handlowego były spółki z ograniczoną odpowiedzialnością. Rzadziej przedsiębiorcy wybierali prowadzenie działalności w postaci spółki akcyjnej, czy jawnej ${ }^{3}$. Należy również zauważyć, że w latach 1999-2003 liczba przedsiębiorstw państwowych należących do sektora publicznego zmalała o $35 \%$ : 
Tab. 1. Liczba przedsiębiorstw w Polsce w latach 1999-2003 według sektorów działalności i form organizacyjno-prawnych (w tys.)

\begin{tabular}{|l|c|c|c|c|c|}
\hline \multicolumn{1}{|c|}{$\begin{array}{c}\text { Wyszczególnienie } \\
\text { (według stanu na 31 grudnia) }\end{array}$} & $\mathbf{1 9 9 9}$ r. & $\mathbf{2 0 0 0}$ r. & $\mathbf{2 0 0 1}$ r. & $\mathbf{2 0 0 2}$ r. & $\mathbf{2 0 0 3}$ r. \\
\hline $\begin{array}{l}\text { Przedsiębiorstwa ogółem } \\
\text { w tym: } \\
\text { A. Sektory działalności przedsiębiorstw }\end{array}$ & $\mathbf{3 0 3 9 , 4 5}$ & $\mathbf{3 1 8 5 , 0 4}$ & $\mathbf{3 3 2 5 , 5 4}$ & $\mathbf{3 4 6 8 , 2 2}$ & $\mathbf{3 5 8 1 , 5 9}$ \\
\hline A1. Sektor publiczny & 83,31 & 98,92 & 110,91 & 120,59 & 129,31 \\
\hline A2. Sektor prywatny & 2956,14 & 3086,12 & 3214,63 & 3347,63 & 3452,28 \\
\hline $\begin{array}{l}\text { B. Formy organizacyjno-prawne, } \\
\text { w tym m.in.: } \\
\text { B1. Przedsiębiorstwa państwowe }\end{array}$ & & & & & \\
\hline B2. Spółki prawa handlowego & 2,6 & 2,3 & 2,1 & 1,9 & 1,7 \\
\hline B3. Spółki cywilne & 146,9 & 159,7 & 177,1 & 196,7 & 208,8 \\
\hline B4. Spółki pozostałe & 288,9 & 302,7 & 290,9 & 280,5 & 279,2 \\
\hline B5. Spółdzielnie & 1,6 & 1,6 & 1,7 & 1,7 & 1,8 \\
\hline B6. Zakłady osób fizycznych & 19,3 & 19,0 & 18,8 & 18,7 & 18,5 \\
\hline
\end{tabular}

Źródło: opracowanie własne ${ }^{4)}$.

z 2,6 tys. w 1999 r. do 1,7 tys. w 2003 r., co związane było $\mathrm{z}$ dalszą restrukturyzacją i prywatyzacją przedsiębiorstw tego sektora.

Analizując przedsiębiorstwa pod względem ich wielkości można zaobserwować tendencję wyraźnej dominacji przedsiębiorstw grupy MŚP. Należy zauważyć, że ustawa z 19 listopada 1999 r. „Prawo działalności gospodarczej” (Dz.U. nr 101, poz. 1178) reguluje pojęcie małego i średniego przedsiębiorstwa. Przyjmując za kryterium liczbę zatrudnionych w przedsiębiorstwie średniorocznie osób przyjmuje się następujące grupy podziału przedsiębiorstw:

- mikroprzedsiębiorstwa, zatrudniające od 0 do 9 pracowników;

- małe przedsiębiorstwa, zatrudniające 10-49 pracowników;
- średnie przedsiębiorstwa, zatrudniające 50-249 pracowników oraz

- duże przedsiębiorstwa, zatrudniające więcej niż 249 pracowników.

W latach 1999-2003 wśród wszystkich przedsiębiorstw działających w Polsce największą grupę stanowiły mikroprzedsiębiorstwa, tj. około 95\% ogółu przedsiębiorstw ${ }^{5}$. W tabeli 2 przedstawiono dane statystyczne dotyczące podziału przedsiębiorstw w 2003 r. według liczby pracujących oraz sekcji PKD.

Jak wynika $\mathrm{z}$ danych, zawartych $\mathrm{w}$ tabeli 2 , największą liczbę przedsiębiorstw według sekcji PKD (Polska Klasyfikacja Działalności) w 2003 r. stanowią przedsiębiorstwa zajmujące się handlem i naprawami, bo blisko $1 / 3$ ogółu przedsiębiorstw w Polsce. Liczną grupę reprezentują także przedsiębiorstwa

Tab. 2. Podział przedsiębiorstw w Polsce według liczby pracujących oraz sekcji PKD w 2003 r. (w tys.)

\begin{tabular}{|l|r|r|r|r|r|r|}
\hline \multicolumn{1}{|c|}{ Wyszczególnienie } & $\mathbf{0 - 9}$ & $\mathbf{1 0 - 4 9}$ & $\mathbf{5 0 - 2 4 9}$ & $\mathbf{2 5 0 - 9 9 9}$ & $\begin{array}{c}\mathbf{1 0 0 0} \\
\text { i więcej }\end{array}$ & Ogółlem \\
\hline $\begin{array}{l}\text { Ogółem, } \\
\text { w tym m.in.: }\end{array}$ & 3410,23 & 137,98 & 28,33 & 4,15 & 0,90 & 3581,59 \\
\hline Górnictwo i kopalnictwo & 1,64 & 0,25 & 0,10 & 0,03 & 0,02 & 2,04 \\
\hline Przetwórstwo przemysłowe & 342,17 & 30,26 & 7,57 & 1,56 & 0,26 & 381,82 \\
\hline $\begin{array}{l}\text { Wytwarzanie i zaopatrywanie w energię elektryczną, } \\
\text { gaz i wodę }\end{array}$ & 2,06 & 0,72 & 0,50 & 0,11 & 0,06 & 3,45 \\
\hline Budownictwo & 345,55 & 12,65 & 2,14 & 0,23 & 0,03 & 360,6 \\
\hline Handel i naprawy & 1168,59 & 27,29 & 3,44 & 0,34 & 0,04 & 1199,7 \\
\hline Hotele i restauracje & 107,63 & 4,14 & 0,28 & 0,02 & - & 112,07 \\
\hline Transport, gospodarka magazynowa i łączność & 265,36 & 3,62 & 0,69 & 0,23 & 0,04 & 269,94 \\
\hline $\begin{array}{l}\text { Obsługa nieruchomości, wynajem, nauka i usługi } \\
\text { związane z prowadzeniem działalności gospodarczej }\end{array}$ & 530,82 & 11,91 & 2,92 & 0,33 & 0,06 & 546,0 \\
\hline Pośrednictwo finansowe & 125,95 & 1,33 & 0,28 & 0,04 & 0,03 & 127,63 \\
\hline
\end{tabular}

Źródło: opracowanie własne ${ }^{6)}$. 
zajmujące się obsługą nieruchomości, wynajmem, nauką i usługami związanymi z prowadzeniem działalności gospodarczej - około 15\% ogółu przedsiębiorstw, przedsiębiorstwa zaliczane do grupy przedsiębiorstw przetwórstwa przemysłowego - około $11 \%$ oraz zaliczane do sekcji budownictwa - około $10 \%$. Najmniejsza liczba przedsiębiorstw wśród wyróżnionych działa w sekcji górnictwa i kopalnictwa - zaledwie 2 tys. przedsiębiorstw. Dane te wskazują, że największa liczba przedsiębiorstw w Polsce to przedsiębiorstwa zajmujące się szeroko rozumianą działalnością usługową.

\section{Sytuacja finansowa przedsiębiorstw w Polsce}

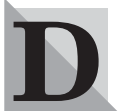

okonując analizy sytuacji finansowej przedsiębiorstw w Polsce zastosowano podział przedsiębiorstw według liczby pracujących, wyróżniając przedsiębiorstwa małe (10-49 pracowników), średnie (50-249 pracowników) i duże (powyżej 249 pracowników). W tabeli 3 przedstawiono podstawowe dane finansowe przedsiębiorstw w Polsce za lata 1999-2003 według ich wielkości.
Przedstawione dane finansowe przedsiębiorstw dotyczą: przychodów i kosztów z całokształtu działalności, wyniku finansowego brutto i netto, stopy rentowności aktywów oraz udziału jednostek rentownych.

W latach 1999-2002 we wszystkich grupach wyszczególnionych przedsiębiorstw, tj. małych, średnich i dużych, zaobserwowano niski, a nawet ujemny poziom rentowności. Dopiero w 2003 r. sytuacja w tym zakresie uległa pewnej poprawie. Wszystkie wyróżnione grupy przedsiębiorstw wykazały bowiem zyski netto. Przedsiębiorstwa duże, które w latach 1999-2002 były deficytowe, w 2003 r. prezentowały już najlepsze wyniki spośród badanych grup przedsiębiorstw. Poprawa w tym zakresie była niewątpliwie skutkiem lepszej koniunktury gospodarczej w Polsce.

Wyraźny wzrost wartości przychodów w latach 1999-2003 odnotowano w grupie dużych przedsiębiorstw, natomiast w przypadku pozostałych grup, tj. małych i średnich przedsiębiorstw, występowały pewne wahania $\mathrm{w}$ tym zakresie. W małych przedsiębiorstwach przychody systematycznie rosły w latach 19992001, po czym w 2002 r. ich wartość uległa zmniejszeniu i dopiero w 2003 r. ponownie wzrosła. W przedsiębiorstwach średniej wielkości przychody rosły w la-

Tab. 3. Dane finansowe przedsiębiorstw w Polsce w latach 1999-2003

\begin{tabular}{|c|c|c|c|c|c|}
\hline Wyszczególnienie & 1999 r. & 2000 r. & 2001 r. & 2002 r. & 2003 r. \\
\hline \multicolumn{6}{|c|}{ Przychody z całokształtu działalności (mld zł) } \\
\hline Przedsiębiorstwa małe & 206,7 & 224,8 & 228,9 & 224,8 & 225,4 \\
\hline Przedsiębiorstwa średnie & 316,1 & 363,4 & 355,7 & 352,9 & 386,2 \\
\hline Przedsiębiorstwa duże & 548,3 & 615,9 & 628,7 & 647,8 & 710,5 \\
\hline \multicolumn{6}{|l|}{ Koszty całokształtu działalności (mld zl) } \\
\hline Przedsiębiorstwa małe & 202,2 & 222,1 & 227,2 & 225,4 & 212,1 \\
\hline Przedsiębiorstwa średnie & 308,2 & 352,1 & 350,6 & 348,4 & 378,1 \\
\hline Przedsiębiorstwa duże & 547,0 & 609,5 & 628,3 & 645,7 & 688,9 \\
\hline \multicolumn{6}{|l|}{ Wynik finansowy brutto (mld z1) } \\
\hline Przedsiębiorstwa małe & 4,6 & 2,7 & 1,7 & $-0,4$ & 11,1 \\
\hline Przedsiębiorstwa średnie & 8,0 & 11,4 & 5,2 & 4,6 & 8,2 \\
\hline Przedsiębiorstwa duże & 2,4 & 6,6 & 0,5 & 2,3 & 21,8 \\
\hline \multicolumn{6}{|l|}{ Wynik finansowy netto (mld zl) } \\
\hline Przedsiębiorstwa małe & 2,0 & 0,8 & $-0,2$ & $-1,7$ & 9,4 \\
\hline Przedsiębiorstwa średnie & 3,5 & 5,8 & 1,5 & 1,7 & 4,9 \\
\hline Przedsiębiorstwa duże & $-4,5$ & $-0,3$ & $-5,0$ & $-3,1$ & 12,8 \\
\hline \multicolumn{6}{|l|}{ Stopa rentowności aktywów (\%) } \\
\hline Przedsiębiorstwa małe & 1,48 & 0,52 & $-0,11$ & $-1,01$ & 5,80 \\
\hline Przedsiębiorstwa średnie & 1,47 & 2,18 & 0,54 & 0,62 & 1,59 \\
\hline Przedsiębiorstwa duże & $-0,92$ & $-0,05$ & $-0,89$ & $-0,52$ & 1,93 \\
\hline \multicolumn{6}{|l|}{ Udział jednostek rentownych (\%) } \\
\hline Przedsiębiorstwa małe & 67,1 & 64,1 & 63,3 & 65,7 & 67,8 \\
\hline Przedsiębiorstwa średnie & 68,6 & 67,5 & 66,2 & 68,1 & 69,9 \\
\hline Przedsiębiorstwa duże & 64,8 & 66,0 & 63,4 & 67,2 & 74,6 \\
\hline
\end{tabular}

Źródło: Przedsiębiorczość w Polsce 2004, MGPiPS, Warszawa 2004, s. 89 [na podstawie PONTINFO na bazie F-02 (1999-2002) oraz CISG na bazie GUS F-01 (2003)]. 
tach 1999-2000, po czym ich wartość do 2002 r. malała, osiągając ostatecznie stosunkowo wysoką wartość w 2003 r. - 386 mld zł.

Pozytywnym zjawiskiem są z pewnością dane dotyczące udziału jednostek rentownych w ogólnej liczbie przedsiębiorstw. W grupie małych przedsiębiorstw wartość tego wskaźnika w latach 1999-2003 utrzymywała się w przedziale $63,3 \%-67,8 \%$, w przedsiębiorstwach średniej wielkości wskaźnik ten osiągał wielkość 66,2\%-69,9\%, a w grupie dużych przedsiębiorstw $63,4 \%-74,6 \%$.Wyniki te świadczą o tym, że w każdej $\mathrm{z}$ analizowanych klas wielkości przedsiębiorstw ponad połowa to były jednostki rentowne, które przynosiły zyski.

W tabeli 4 przedstawiono podstawowe dane dotyczące zadłużenia i płynności finansowej przedsię- biorstw w Polsce, ujęte w podziale według wielkości przedsiębiorstw.

$\mathrm{Z}$ analizy danych zebranych w tabeli $4 \mathrm{w}$ badanym okresie lat 1999-2003 można zauważyć wyraźny wzrost zobowiązań długo- i krótkoterminowych w grupie przedsiębiorstw dużych z 227,5 mld zł w 1999 r. do poziomu 289,0 mld zł w 2003 r (wzrost o 27\%). Dość duży wzrost w tym zakresie odnotowano także $\mathrm{w}$ grupie przedsiębiorstw średniej wielkości z poziomu 114,9 mld zł w 1999 r. do poziomu 143,2 mld zł w 2003 r. (wzrost o 25\%), zaś najmniejszy w grupie małych przedsiębiorstw z 73,8 mld zł w 1999 r. do 83,7 mld zł w 2003 r. (wzrost o 13\%). W strukturze zobowiązań w latach 1999-2003 nie zaszły znaczące zmiany, gdyż w całym okresie dominującą ich część stanowiły zobowiązania krótkoterminowe. Udział zo-

Tab. 4. Dane bilansowe oraz wskaźniki zadłużenia i płynności przedsiębiorstw w Polsce w latach 1999-2003

\begin{tabular}{|c|c|c|c|c|c|}
\hline Wyszczególnienie & 1999 r. & 2000 r. & 2001 r. & 2002 r. & 2003 r. \\
\hline \multicolumn{6}{|l|}{ Zobowiązania krótkoterminowe (mld zl) } \\
\hline Przedsiębiorstwa małe & 52,2 & 58,4 & 62,5 & 66,1 & 60,8 \\
\hline Przedsiębiorstwa średnie & 78,5 & 90,5 & 94,5 & 94,5 & 99,7 \\
\hline Przedsiębiorstwa duże & 154,8 & 173,3 & 178,3 & 191,1 & 175,3 \\
\hline \multicolumn{6}{|l|}{ Zobowiązania długoterminowe (mld zl) } \\
\hline Przedsiębiorstwa małe & 21,6 & 24,9 & 25,6 & 27,1 & 22,9 \\
\hline Przedsiębiorstwa średnie & 36,4 & 37,2 & 35,9 & 32,8 & 43,5 \\
\hline Przedsiębiorstwa duże & 72,7 & 85,7 & 102,0 & 101,6 & 113,7 \\
\hline \multicolumn{6}{|l|}{$\begin{array}{l}\text { Udział zobowiązań długoterminowych } \\
\text { w wartości ogółem (\%) }\end{array}$} \\
\hline Przedsiębiorstwa małe & 29,3 & 29,9 & 29,0 & 29,1 & 27,4 \\
\hline Przedsiębiorstwa średnie & 31,7 & 29,2 & 27,5 & 25,7 & 30,4 \\
\hline Przedsiębiorstwa duże & 32,0 & 33,1 & 36,4 & 34,7 & 39,3 \\
\hline \multicolumn{6}{|c|}{ Współczynnik długu (zobowiązania /aktywa) } \\
\hline Przedsiębiorstwa małe & 0,60 & 0,61 & 0,63 & 0,59 & 0,52 \\
\hline Przedsiębiorstwa średnie & 0,56 & 0,54 & 0,53 & 0,51 & 0,47 \\
\hline Przedsiębiorstwa duże & 0,53 & 0,55 & 0,58 & 0,57 & 0,44 \\
\hline \multicolumn{6}{|l|}{ Zobowiązania/ kapitał własny } \\
\hline Przedsiębiorstwa małe & 1,48 & 1,59 & 1,69 & 1,42 & 1,59 \\
\hline Przedsiębiorstwa średnie & 1,25 & 1,20 & 1,14 & 1,03 & 1,04 \\
\hline Przedsiębiorstwa duże & 1,13 & 1,24 & 1,38 & 1,30 & 1,22 \\
\hline \multicolumn{6}{|l|}{ Wskaźnik płynności } \\
\hline Przedsiębiorstwa małe & 0,99 & 0,94 & 0,90 & 1,05 & 1,18 \\
\hline Przedsiębiorstwa średnie & 0,93 & 0,98 & 0,97 & 1,15 & 1,21 \\
\hline Przedsiębiorstwa duże & 0,85 & 0,81 & 0,78 & 1,01 & 1,20 \\
\hline \multicolumn{6}{|c|}{ Wskaźnik podwyższonej płynności finansowej } \\
\hline Przedsiębiorstwa małe & 0,71 & 0,68 & 0,65 & 0,77 & 0,86 \\
\hline Przedsiębiorstwa średnie & 0,66 & 0,69 & 0,70 & 0,83 & 0,88 \\
\hline Przedsiębiorstwa duże & 0,58 & 0,57 & 0,56 & 0,74 & 0,86 \\
\hline
\end{tabular}

Źródło: Przedsiębiorczość w Polsce 2004, MGPiPS, Warszawa 2004, s. 94, 95 [na podstawie PONTINFO na bazie F-02 (1999-2002) oraz CISG na bazie GUS F-01 (2003)]. 
bowiązań długoterminowych kształtował się generalnie na poziomie około $30 \%$ dla małych i średnich przedsiębiorstw. W przypadku dużych przedsiębiorstw udział zobowiązań długoterminowych w wartości ogółem kształtował się na poziomie $32,0 \%-39,3 \%$.

Współczynnik długu, wyrażony relacją zobowiązania/aktywa, obrazuje strukturę finansową majątku przedsiębiorstw. W latach 1999-2003 największą wartość współczynnik ten osiągnął w grupie małych przedsiębiorstw - 0,60 w 1999 r. oraz 0,52 w 2003 r., zaś najniższą jego wartość odnotowano w grupie przedsiębiorstw dużych 0,53 w 1999 r. oraz 0,44 w 2003 r. Poziom ten $(0,44-0,63)$ nie odbiega od wartości przyjmowanych za optymalne dla przedsiębiorstw. Jednakże utrzymywanie się tendencji wzrostowej wskaźnika w dłuższym okresie należy ocenić negatywnie; może to skutkować wzrostem liczby przedsiębiorstw o zachwianej płynności oraz niezdolnych do obsługi swego długu.

Wskaźniki płynności w grupie badanych przedsiębiorstw utrzymywały się na poziomie poniżej wielkości uznawanej za optymalną. W latach 1999-2002 duże przedsiębiorstwa wykazywały najniższą wartość wskaźników płynności w porównaniu do małych i średnich przedsiębiorstw. W 2003 r. odnotowano pewną poprawę w tym zakresie w grupie wszystkich wyróżnionych grup przedsiębiorstw.

W tabeli 5 zebrano podstawowe dane dotyczace działalności eksportowej i inwestycyjnej przedsiębiorstw w Polsce w latach 1999-2003.

$\mathrm{Z}$ danych, zawartych w tabeli 5 wynika, że wśród wyróżnionych grup przedsiębiorstw najmniejszy udział sprzedaży eksportowej w przychodach netto cechował małe firmy. Jest to niewątpliwie związane z działalnością lokalna, regionalna, czy krajową wśród tych przedsiębiorstw. W grupie przedsiębiorstw średniej i dużej wielkości udział ten sukcesywnie zwiększał się. Wśród przedsiębiorstw średniej wielkości wyniósł on $5,0 \%-11,9 \%$, a wśród dużych przedsiębiorstw 13,0\%-18,9\%. Najwyższą dynamikę sprzedaży w tych przedsiębiorstwach odnotowano w latach 2002-2003. Wzrost sprzedaży eksportowej to także niewątpliwie konsekwencja dokonujących się procesów globalizacyjnych gospodarki światowej, a także postępującej integracji Polski z Unią Europejską.

Analizując aktywność inwestycyjną przedsiębiorstw w Polsce można zaobserwować zbliżone tendencje we wszystkich grupach wielkości przedsiębiorstw. W latach 1999-2000 inwestycje utrzymywały się na stabilnym poziomie, jednakże w 2001 r. doszło do ich załamania. W latach 2001-2003 wartość nakładów inwestycyjnych utrzymywała się na podobnym poziomie w wybranych grupach wielkości przedsiębiorstw. W wartościach bezwzględnych największe nakłady inwestycyjne były ponoszone wśród dużych przedsiębiorstw: 50,8 mld zł w 1999 r. i 41,7 mld zł w 2003 r. Najbardziej dotkliwie spadek nakładów inwestycyjnych został odnotowany wśród małych przedsiębiorstw, gdzie jego wartość spadła o blisko $30 \%$ (z 10,7 mld zł w 1999 r. do 7,6 mld zł w 2003 r.).

\section{Podsumowanie}

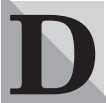

okonany przegląd statystycznych materiałów źródłowych za lata 1999-2003 z zakresem zmian strukturalnych przedsiębiorstw w Pol-

Tab. 5. Wskaźniki działalności eksportowej i aktywności inwestycyjnej przedsiębiorstw w Polsce w latach 1999-2003

\begin{tabular}{|c|c|c|c|c|c|}
\hline Wyszczególnienie & 1999 r. & 2000 r. & 2001 r. & 2002 r. & 2003 r. \\
\hline \multicolumn{6}{|c|}{ Udzial sprzedaży eksportowej w przychodach netto [\%] } \\
\hline Przedsiębiorstwa małe & 4,0 & 3,0 & 4,0 & 6,0 & 7,3 \\
\hline Przedsiębiorstwa średnie & 5,0 & 6,0 & 7,0 & 9,0 & 11,9 \\
\hline Przedsiębiorstwa duże & 13,0 & 14,0 & 14,0 & 16,0 & 18,9 \\
\hline \multicolumn{6}{|l|}{ Dynamika sprzedaży eksportowej [\%] } \\
\hline Przedsiębiorstwa małe & 423,0 & 83,7 & 109,4 & 209,8 & 121,6 \\
\hline Przedsiębiorstwa średnie & 105,8 & 140,3 & 102,9 & 144,5 & 143,9 \\
\hline Przedsiębiorstwa duże & 109,5 & 121,7 & 100,5 & 120,1 & 126,1 \\
\hline \multicolumn{6}{|c|}{ Wartość nakładów inwestycyjnych* (mld zl) } \\
\hline Przedsiębiorstwa małe & 10,7 & 11,9 & 8,3 & 7,6 & 7,6 \\
\hline Przedsiębiorstwa średnie & 22,5 & 21,7 & 15,9 & 15,5 & 15,3 \\
\hline Przedsiębiorstwa duże & 50,8 & 52,0 & 43,0 & 42,4 & 41,7 \\
\hline \multicolumn{6}{|c|}{$\begin{array}{l}\text { Wartość nakładów inwestycyjnych na } 1 \text { przedsiębiorstwo } \\
\text { [tys. zł] }\end{array}$} \\
\hline Przedsiębiorstwa małe & 369,0 & 407,1 & 257,2 & 269,1 & 287,0 \\
\hline Przedsiębiorstwa średnie & 1593,3 & 1555,5 & 1195,1 & 1200,6 & 1161,2 \\
\hline Przedsiębiorstwa duże & 15855,2 & 16851,9 & 15195,5 & 15451,3 & 15944,0 \\
\hline
\end{tabular}

* razem z używanymi środkami trwałymi.

Źródło: opracowanie własne ${ }^{7}$. 
sce oraz zmian ich sytuacji finansowej umożliwia właściwy pogląd na istotę zaistniałych zmian organizacyjno-prawnych, sektorowych, w rodzajach prowadzonych działalności oraz w sytuacji finansowej przedsiębiorstw.

I tak na przykład w latach 1999-2003 następował systematyczny wzrost ogólnej liczby przedsiębiorstw od 3039,45 tys. w 1999 r. do 3581,59 tys. w 2003 r., co stanowi przyrost ilościowy przedsiębiorstw o około $18 \%$, w tym liczbowo przede wszystkim w grupie „zakłady osób fizycznych" z 2417,7 tys. w 1999 r. do 2795,9 tys. w 2003 r. Świadczyć to może z jednej strony o zaistnieniu sprzyjających warunków do powstawania nowych przedsiębiorstw, z drugiej zaś strony o podejmowanych próbach samodzielnego prowadzenia działalności gospodarczej przez osoby fizyczne, nie znajdujace zatrudnienia na bardzo ograniczonym rynku pracy. Z analizy ilościowej przedsiębiorstw działających w 2003 r. w różnych dziedzinach gospodarczych wynika, że około 1/3 ogółu przedsiębiorstw w Polsce funkcjonowało w handlu i usługach. Stosunkowo liczne grupy reprezentowały w kolejności przedsiębiorstwa zajmujące się obsługą nieruchomości, wynajmem, nauka i usługami związanymi z prowadzeniem działalności gospodarczej - około 15\% ogółu przedsiębiorstw, przetwórstwem przemysłowym - około $11 \%$ oraz budownictwem - około $10 \%$. Najmniejsza grupe stanowiły przedsiębiorstwa działające w górnictwie i kopalnictwie - około 0,057\% ogółu przedsiębiorstw. Dane te świadcza o tym, że w Polsce dominują ilościowo przedsiębiorstwa zajmujące się szeroko rozumianą działalnością usługową.

Sytuacja finansowa przedsiębiorstw w Polsce w latach 1999-2003 była zróżnicowana. Wprawdzie we wszystkich grupach przedsiębiorstw, tj. małych, średnich i dużych ponad $60 \%$ stanowiły przedsiębiorstwa rentowne, to jednak uwage zwraca stosunkowo duży udział przedsiębiorstw nierentownych. Dobrym sygnałem w tym zakresie jest zaobserwowany w latach 2002-2003 wzrost udziału ilościowego przedsiębiorstw rentownych we wszystkich grupach przedsiębiorstw, przy czym największy w grupie dużych przedsiębiorstw. Wskazuje to na ogólną poprawę sytuacji finansowej przedsiębiorstw w Polsce w ostatnich latach. Świadczy o tym również zauważalny wzrost udziału sprzedaży eksportowej w przychodach netto oraz dynamiki sprzedaży eksportowej we wszystkich grupach przedsiębiorstw. Nieco niepokojącym zjawiskiem jest zmniejszająca się w ostatnich latach bezwzględna wartość nakładów inwestycyjnych we wszystkich grupach przedsiębiorstw, może się to bowiem odbić niekorzystnie na ich dalszym rozwoju.

mgr Barbara Siuta

Katedra Ekonomiki i Organizacji Przedsiębiorstw Akademia Ekonomiczna w Krakowie

\section{PRZYPISY}

1) Zmiany strukturalne grup podmiotów gospodarki narodowej $w 2003$ r., GUS, Warszawa 2004.

2) Ibidem.

3) Przedsiębiorczość w Polsce 2004, Ministerstwo Gospodarki i Pracy, Warszawa, czerwiec 2004, s. 82.

4) Na podstawie: Zmiany strukturalne grup podmiotów gospodarki narodowej $w 2003$ r., GUS, Warszawa 2004, s. 30-31.

5) Dane wyliczone na podstawie informacji PARP, statystyk w latach 1999-2002, PARP, Warszawa 2004 oraz dane GUS dotyczące podziału przedsiębiorstw według klas wielkości $\mathrm{w} 2003$ r.Zmiany strukturalne grup podmiotów gospodarki narodowej w 2003 r., GUS, Warszawa 2004, s. 34.

6) Na podstawie: Zmiany strukturalne..., GUS, Warszawa 2004 , s. 34-49.

7) Na podstawie: Przedsiębiorczość w Polsce 2004, MGiP, Warszawa 2004, s. 96-98, dane wyliczone na podstawie PONTINFO na bazie F-02 (1999-2002) oraz CISG na bazie GUS F-01 (2003).

\section{BIBLIOGRAFIA}

[1] Przedsiębiorczość w Polsce 2004, Ministerstwo Gospodarki i Pracy, Warszawa, czerwiec 2004.

[2] Zmiany strukturalne grup podmiotów gospodarki narodowej w 2003 r., GUS, Warszawa 2004. 